\title{
Growth of Lactobacillus casei FNCC0900 in Media Based Umbi Porang Plant (Amorphophallus muelleri BI.)
}

\author{
(Pertumbuhan Lactobacillus casei FNCC0900 Pada Media Berbasis Umbi Tanaman Porang \\ (Amorphophallus muelleri BI.))
}

\author{
Fitri Azhari*), Rudju Winarsa, Siswanto, Kahar Muzakhar, Esti Utarti, Sutoyo, Sattya Arimurti \\ Jurusan Biologi, Fakultas Matematika dan Ilmu Pengetahuan Alam, Universitas Jember \\ Jl. Kalimantan 37, Jember 68121
}

\section{ABSTRACT}

Porang tuber (Amorphophallus muellerii BI.) Is a type of tuber that has a high enough glucomannan content of $67 \%$. Glucomannan is very difficult to digest by humans directly so it takes the role of probiotics. L. casei bacteria FNCC0900 as a probiotic agent capable of utilizing glucomannan as a carbon source for growth. The purpose of this study was to determine the growth pattern and changes in environmental factors, namely the $\mathrm{pH}$ value of the probiotic bacteria L. casei FNCC0900 growth medium. The parameters in this study consisted of the highest cell density, generation time and $\mathrm{pH}$ value changes in Glucose Yeast Peptone Liquid Media, Porang Boiled Water Media and Porang Flour Liquid Media using the drop plate method which had 4 repeated calculations. Porang Boiled Water Liquid Media has a faster log phase period with a higher cell density than Porang Flour Liquid Media, but the shortest generation time is found in Porang Flour Liquid Media with the highest number of generations. L. casei FNCC0900 bacteria are more able to reduce the $\mathrm{pH}$ of Glucose Yeast Peptone Liquid Media compared to porang tuber-based media, so in this case L. casei FNCC0900 can be stated to be able to grow on porang tuber-based media with growth patterns, generation time, cell density and $\mathrm{pH}$ value. which varies.

Umbi porang (Amorphophallus muellerii BI.) merupakan salah satu jenis umbi yang memiliki kandungan glukomannan cukup tinggi sebesar 67\% . Glukomannan sangat sulit dicerna oleh manusia secara langsung sehingga dibutuhkan peran probiotik. Bakteri L. casei FNCC0900 sebagai agen probiotik yang mampu memanfaatkan glukomannan sebagai sumber karbon untuk pertumbuhannya. Tujuan dari penelitian ini untuk mengetahui pola pertumbuhan dan perubahan faktor lingkungan yaitu nilai pH pada media pertumbuhan bakteri probiotik L. casei FNCC0900. Parameter dalam penelitian ini terdiri atas kepadatan sel tertinggi, waktu generasi dan perubahan nilai pH pada Media Cair Glucose Yeast Peptone, Media Air Rebusan Porang dan Media Cair Tepung Porang dengan metode drop plate yang memiliki 4 kali ulangan perhitungan. Media Cair Air Rebusan Porang memiliki periode fase log yang lebih cepat dengan kepadatan sel lebih tinggi dibandingkan Media Cair Tepung Porang, namun waktu generasi paling singkat terdapat pada Media Cair Tepung Porang dengan jumlah generasi paling tinggi. Bakteri L. casei FNCC0900 lebih mampu menurunkan pH Media Cair Glucose Yeast Peptone dibandingkan pada media berbasis umbi porang, sehingga dalam hal ini L. casei FNCC0900 dapat dinyatakan mampu tumbuh pada media berbasis umbi porang dengan pola pertumbuhan, waktu generasi, kepadatan sel serta nilai $\mathrm{pH}$ yang bervariasi.

Keywords: Lactobacillus casei, Growth, pH, Porang tubers.

$\left.{ }^{*}\right)$ Corresponding author:

Fitri Azhari

E-mail: fitriazhari86@gmail.com

\section{PENDAHULUAN}

Indonesia merupakan salah satu negara yang memiliki berbagai macam jenis umbi-umbian yang dapat berpotensi sebagai bahan pangan fungsional [1]. Umbi-umbian sangat cocok digunakan sebagai medium fermentasi, karena memiliki kandungan nutrisi yang tinggi seperti karbohidrat berupa oligosakarida serta serat pangan yang berpotensi sebagai prebiotik [2]. Prebiotik adalah bahan pangan dengan kandungan oligosakarida yang sulit dicerna 
oleh manusia namun dapat memiliki manfaat bagi pertumbuhan mikrobiota pada saluran pencernaan [3].

Oligosakarida disebut sebagai prebiotik karena dapat berperan sebagai media yang baik untuk pertumbuhan bakteri yang menguntungkan di dalam saluran pencernaan [4]. Umbi porang (Amorphophallus muelleri BI.) merupakan salah satu jenis umbi yang banyak tumbuh di Indonesia, namun pemanfaatannya masih kurang optimal oleh masyarakat. Umbi porang memiliki potensi sebagai pangan fungsional dengan nilai indeks glikemik yang rendah yaitu 16,9\% [1].

Pangan dengan nilai indeks glikemik yang rendah $(<55)$ mampu menurunkan kadar gula darah dalam tubuh sehingga umbi porang dapat dimanfaatkan sebagai bahan pangan fungsional yang memiliki manfaat bagi kesehatan, terutama bagi penderita diabetes [5]. Pangan fungsional adalah pangan segar atau yang diolah dalam bentuk apapun untuk memenuhi kebutuhan nutrisi dalam tubuh dan bermanfaat bagi kesehatan [6]. Umbi porang juga termasuk dalam salah satu pangan prebiotik [7].

Komposisi kimia pada tepung umbi porang terdiri atas air $(6,8 \%)$, abu $(7,9 \%)$, pati $(10,2 \%)$, protein (3,4\%), lemak (3\%) dan kalsium oksalat (22,7\%) [8]. Umbi porang juga mengandung glukomannan yang cukup tinggi yaitu sebesar 67\%. Protein pada umbi porang yang berikatan dengan glukomannan disebut dengan lektin, lektin memiliki sifat antibakteri terhadap bakteri Eschericia coli dan Staphylococcus aureus [9].

Kandungan glukomannan pada umbi porang mampu dimanfaatkan oleh bakteri $L$. casei sebagai sumber karbon. Glukomannan merupakan polisakarida dengan ikatan glukosa dan mannosa sebagai rantai utama. Glukomannan sangat sulit dicerna oleh manusia secara langsung sehingga membutuhkan peran bakteri probiotik salah satunya L. casei untuk mempermudah proses pencernaan Glukomannan di dalam tubuh manusia [7].

Penelitian ini bertujuan untuk mengetahui pola pertumbuhan dan perubahan faktor lingkungan yaitu nilai $\mathrm{pH}$ pada media pertumbuhan bakteri probiotik $L$. casei FNCC0900. Pemanfaatan bakteri L. casei sebagai agen probiotik pada penelitian ini dikarenakan bakteri L. casei mampu memanfaatkan komponen gula, pati dan serat pada umbi sebagai sumber karbon untuk mendukung pertumbuhannya dengan cara memecah oligosakarida menjadi asam laktat [10]. Keunggulan lain dari pemanfaatan bakteri $L$. casei sebagai agen probiotik yaitu L. casei mampu tahan pada $\mathrm{pH}$ yang rendah, mampu tumbuh pada media pertumbuhan alami baik pada biji, sayuran dan umbi [11].

Probiotik merupakan sel mikroba hidup yang memiliki manfaat bagi kesehatan dengan cara menyeimbangkan aktivitas mikroba pada saluran pencernaan serta memiliki aktivitas pertumbuhan yang tinggi pada saluran pencernaan [10]. Media pertumbuhan berbasis umbi porang yang digunakan sangat mempengaruhi pola pertumbuhan L. casei dalam memanfaatkan beberapa komposisi kimia pada umbi porang terutama glukomannan. Pola pertumbuhan L. casei pada media berbasis umbi porang diharapkan jauh lebih optimal dibandingkan pada media kontrol.

\section{METODE PENELITIAN}

\section{Bahan Penelitian}

Bahan yang digunakan dalam penelitian ini adalah kultur murni bakteri asam laktat Lactobacillus casei FNCC 0900 dari Universitas Gadjah Mada Yogyakarta dan umbi porang (A. muelleri) yang didapatkan dari Jember.

\section{Tahapan Persiapan Penelitian}

\section{Pembuatan Media Padat GYP (Glucose Yeast Pepton)}

Pembuatan Media Padat GYP dilakukan dengan cara memasukkan 1 gram glukosa, 1 gram yeast extract, 0.2 gram beef extract, 0.5 pepton, $\mathrm{Na}$-Asetat sebanyak 0.14 gram, Salt solution sebanyak $0.5 \mathrm{~mL}$ dan Tween 80 sebanyak $1 \mathrm{~mL}$ dalam Beaker Glass $100 \mathrm{~mL}$. $\mathrm{CaCO}_{3}$ sebanyak 0,5 gram dan Bacto Agar sebanyak 1,2 gram juga ditambahkan ke dalam Beaker Glass $100 \mathrm{~mL}$. Bahan-bahan yang telah homogen kemudian dipanaskan dengan hot plate hingga mendidih, selanjutnya dituang dalam tabung reaksi sebanyak 10 $\mathrm{mL}$ dan disterilkan ke dalam autoklaf selama 25 menit dengan suhu $121{ }^{\circ} \mathrm{C}$. Media yang telah steril akan dituang ke dalam cawan petri steril jika sudah hangat, kemudian disimpan pada suhu ruang.

\section{Pembuatan Media Cair GYP (Glucose Yeast Pepton)}

Pembuatan Media Cair GYP dilakukan dengan memasukkan 1 gram glukosa, 1 gram yeast extract, 0.2 gram beef extract, 0.5 pepton, $\mathrm{Na}$-Asetat sebanyak 0.14 gram, Salt solution sebanyak $0.5 \mathrm{~mL}$ dan Tween 80 sebanyak $1 \mathrm{~mL}$ dalam Beaker Glass 100 mL. Bahan- 
bahan yang telah homogen, kemudian dipanaskan dengan hot plate hingga mendidih, kemudian Media Cair GYP yang telah mendidih akan dituang dalam labu Erlenmeyer $200 \mathrm{~mL}$ untuk disterilkan ke dalam autoklaf selama 25 menit dengan suhu $121^{\circ} \mathrm{C}$. Media Cair GYP yang telah steril, kemudian disimpan pada suhu ruang.

\section{Pembuatan Media Cair Air Rebusan Porang}

Pembuatan Media Cair Air Rebusan Porang dilakukan dengan merebus 10 gram umbi porang dengan $50 \mathrm{~mL}$ akuades di dalam Beaker glass. Proses perebusan dilakukan dengan menggunakan hot plate sampai mendidih, kemudian Media Cair Air Rebusan Porang yang telah mendidih akan dituang dalam labu Erlenmeyer $200 \mathrm{~mL}$ untuk disterilkan ke dalam autoklaf selama 25 menit dengan suhu $121^{\circ} \mathrm{C}$. Media Cair Air Rebusan Porang yang telah steril, kemudian disimpan pada suhu ruang.

\section{Pembuatan Tepung Porang}

Pembuatan tepung porang diawali dengan pengupasan umbi porang segar dan pencucian yang kemudian diiris dan direndam dalam air yang telah ditambah $\mathrm{CaCO}_{3}$ dengan perbandingan 1:1. Umbi porang diiris tipis dengan ketebalan 1-2 mm. Pengirisan umbi dilakukan untuk mempercepat proses pengeringan. Irisan umbi dikeringkan dengan oven pada suhu sekitar $50{ }^{\circ} \mathrm{C}$ hingga berat umbi konstan. Hasil pengeringan berupa serpihan kering porang yang kemudian digiling dan disaring dengan menggunakan saringan ukuran 100-120 mesh untuk menghasilkan tepung porang yang halus.

\section{Pembuatan Media Cair Tepung Porang}

Pembuatan Media Cair Tepung Porang dilakukan dengan merebus 0,5 gram tepung porang dengan 50 $\mathrm{mL}$ akuades ke dalam Beaker glass. Proses perebusan dilakukan dengan menggunakan hot plate sampai mendidih selanjutnya, Media Cair Tepung Porang yang telah mendidih akan dituang dalam labu Erlenmeyer $200 \mathrm{~mL}$ untuk disterilkan ke dalam autoklaf selama 25 menit dengan suhu $121^{\circ} \mathrm{C}$. Media Cair Tepung Porang yang telah steril, kemudian disimpan pada suhu ruang.

\section{Tahapan Pembuatan Suspensi Inokulum Bakteri L. casei FNCC0900 \\ Peremajaan bakteri L. casei FNCC0900}

Peremajaan bakteri dilakukan dengan menginokulasikan 1 ose L. casei FNCC0900 pada Media Padat GYP dengan metode gores kemudian diinkubasi pada suhu $37^{\circ} \mathrm{C}$ selama 24 jam. Pertumbuhan L. casei FNCC0900 ditandai dengan adanya zona bening di sekitar koloni. Bakteri yang tumbuh kemudian diambil 1 ose dan digoreskan pada Media Padat GYP miring dan diinkubasi pada suhu $37^{\circ} \mathrm{C}$ selama 24 jam.

\section{Pembuatan suspensi inokulum}

Pembuatan suspensi inokulum dilakukan dengan mengambil 1 ose dari stok bakteri L. casei FNCC0900 pada $50 \mathrm{~mL}$ Media Cair Glucose Yeast kemudian diinkubasi pada shaker $100 \mathrm{rpm}$ selama 18 jam pada suhu $37^{\circ} \mathrm{C}$. Kepadatan sel yang diinginkan yaitu sebesar $10^{7}$ (CFU/mL).

Kepadatan sel diperoleh dengan melakukan pembuatan kurva standart. Kurva standart dibentuk berdasarkan hasil perhitungan nilai absorbansi (OD) dan perhitungan jumlah koloni bakteri dengan metode Total Plate Count (TPC) dari sampel suspense inokulum. Data hasil perhitungan nilai absorbansi (OD) dan Total Plate Count (TPC) yang telah didapatkan kemudian diolah untuk menjadi kurva standart dengan rumus sebagai berikut:

$$
\begin{aligned}
& \mathrm{y}=0.3302 \mathrm{x}-2.4905 \\
& \text { Antilog } \mathrm{x}=\ldots \ldots \ldots \ldots \ldots
\end{aligned}
$$

Keterangan :

$$
\begin{aligned}
x= & \text { Jumlah sel yang akan diinokulasikan } \\
y= & \text { Nilai absorbansi dari masing-masing media } \\
& \text { perlakuan yang telah diinokulasikan kultur } \\
& \text { bakteri L. casei FNCC0900 }
\end{aligned}
$$

Hasil perhitungan yang telah diperoleh kemudian dimasukkan ke dalam rumus perhitungan sebagai berikut:

$$
\mathrm{n} 1 \cdot \mathrm{v} 1=\mathrm{n} 2 \cdot \mathrm{v} 2
$$

Keterangan:

n1 : Jumlah kepadatan sel (CFU/mL)

v1 : Volume Starter yang diinokulasikan pada media perlakuan

n2 : Ketentuan jumlah kepadatan sel (umumnya untuk peluang tumbuh yaitu $10^{6}-10^{7}$ )

v2 : 10\% dari volume starter $(5 \mathrm{~mL})$

Berdasarkan hasil perhitungan tersebut, maka akan diperoleh kepadatan sel dan volume starter yang akan diinokulasikan pada media perlakuan. 
Tahapan Uji Pertumbuhan L. casei FNCC0900 pada Media Pertumbuhan

Pengukuran perubahan nilai $\mathrm{pH}$ awal dan akhir pada media pertumbuan

Pengukuran nilai $\mathrm{pH}$ pada masing-masing media pertumbuhan dilakukan dengan menyiapkan Media Cair GYP, Media Cair Air Rebusan Porang, dan Media Cair Tepung Porang steril. Masing-masing media pertumbuhan diambil $1 \mathrm{~mL}$ untuk dimasukkan ke dalam Eppendorf dengan cara yang aseptis di dalam Laminar Air Flow. Pengukuran nilai pH awal masingmasing media pertumbuhan dilakukan dengan mencelupkan kertas $\mathrm{pH}$ ke dalam masing-masing media pertumbuhan, kemudian pembacaan nilai $\mathrm{pH}$ dilakukan dengan mencocokkan perubahan warna pada kertas $\mathrm{pH}$ dengan nilai $\mathrm{pH}$. Hal tersebut juga dilakukan untuk pengukuran nilai $\mathrm{pH}$ akhir pada masing-masing media pertumbuhan.

\section{Inokulasi bakteri L. casei FNCC0900 pada media pertumbuhan}

Langkah pertama untuk menumbuhkan bakteri $L$. casei FNCC0900 adalah menyiapkan masing-masing media pertumbuhan yang akan digunakan. Kultur bakteri L. casei FNCC0900 sebanyak $5 \mathrm{~mL}(10 \%$ dari $50 \mathrm{~mL}$ volume starter) dengan kepadatan sel dari hasil pembuatan kurva standart sebesar $10^{7}(\mathrm{CFU} / \mathrm{mL})$ diinokulasikan ke dalam 3 jenis media pertumbuhan (masing-masing 1 kali sampling). Kultur L. casei FNCC0900 kemudian diinkubasi pada shaker $100 \mathrm{rpm}$ selama 24 jam pada suhu ruang.

\section{Pembuatan pola pertumbuhan bakteri $L$. casei FNCC0900 FNCC0900}

Pembuatan pola pertumbuhan bakteri dilakukan dengan menginokulasikan bakteri L. casei FNCC0900 pada Media Cair GYP, Media Cair Air Rebusan Porang dan Media Cair Tepung Porang dengan kepadatan sel sebesar $10^{7}(\mathrm{CFU} / \mathrm{mL})$ dan diinkubasi pada shaker dengan kecepatan $100 \mathrm{rpm}$ pada suhu ruang selama 48 jam. Setiap interval 4 jam, dilakukan sampling dengan mengambil $1 \mathrm{~mL}$ inokulum untuk dimasukkan ke dalam $9 \mathrm{~mL}$ garam fisiologis $0,85 \% \mathrm{NaCl}$ sebagai pengenceran $10^{-1}$, kemudian dimasukkan $100 \mu \mathrm{l}$ ke dalam eppendorf yang berisi $900 \mu$ garam fisiologis sebagai pengenceran $10^{-2}$ dan dilakukan sampai pengenceran $10^{-8}$. Masing-masing seri pengenceran diambil $10 \mu \mathrm{l}$ untuk diinokulasikan dengan metode tetes (drop plate) pada Media Padat Glucose Yeast Peptone, kemudian diinkubasi pada suhu $37^{\circ} \mathrm{C}$ selama 48 jam dan diulangi hingga 4 kali ulangan perlakuan.

Perhitungan jumlah sel bakteri dilakukan menggunakan SPC (Standart Plate Count) dengan rumus:

$$
\begin{gathered}
\qquad \text { Koloni }(\mathrm{CFU} / \mathrm{mL})= \\
\sum \text { koloni per cawan } \times \frac{1000}{10} \times \frac{1}{\text { faktor pengenceran }}
\end{gathered}
$$

\section{Analisis Data}

Analisis data dilakukan dengan cara deskriptif yang disajikan melalui tabel dan gambar. Data diperoleh berdasarkan perhitungan kepadatan sel, waktu generasi bakteri L. casei FNCC0900 yang tumbuh pada Media Cair GYP dan media berbasis umbi porang serta perubahan nilai $\mathrm{pH}$ pada Media Cair GYP dan media berbasis umbi porang. Waktu generasi bakteri L. casei FNCC0900 dihitung 1 kali yang diperoleh dari kepadatan sel L. casei FNCC0900 pada fase eksponensial (log).

Rumus perhitungan jumlah generasi sebagai berikut:

Keterangan:

$$
\mathrm{n}=\frac{\log \mathrm{Nt}-\log \mathrm{No}}{\log 2}
$$

$\mathrm{n}$ : Jumlah generasi

$\mathrm{Nt}$ : Jumlah sel akhir (CFU/mL)

No : Jumlah sel awal (CFU/mL)

Waktu generasi dapat dihitung dengan rumus:

$$
\mathrm{G}=\frac{\mathrm{n}}{\mathrm{t}}
$$

Keterangan:

G : Waktu generasi (generasi/menit)

n : Jumlah generasi

t : Waktu pertumbuhan (menit). 


\section{HASIL DAN PEMBAHASAN}

\section{Pola Pertumbuhan Lactobacillus casei FNCC0900}

Berdasarkan hasil yang didapatkan, bakteri L. casei FNCC0900 memiliki empat fase pada pola pertumbuhannya yang terdiri atas fase lag (adaptasi), fase eksponensial (logaritmik), fase stasioner dan fase kematian yang memiliki lama fase berbeda-beda pada masing-masing media pertumbuhan. Media pertumbuhan yang digunakan terdiri atas Media Cair GYP, Media Cair Air Rebusan Porang dan Media Cair Tepung Porang, pola pertumbuhan L. casei FNCC0900 disajikan pada Gambar 1.

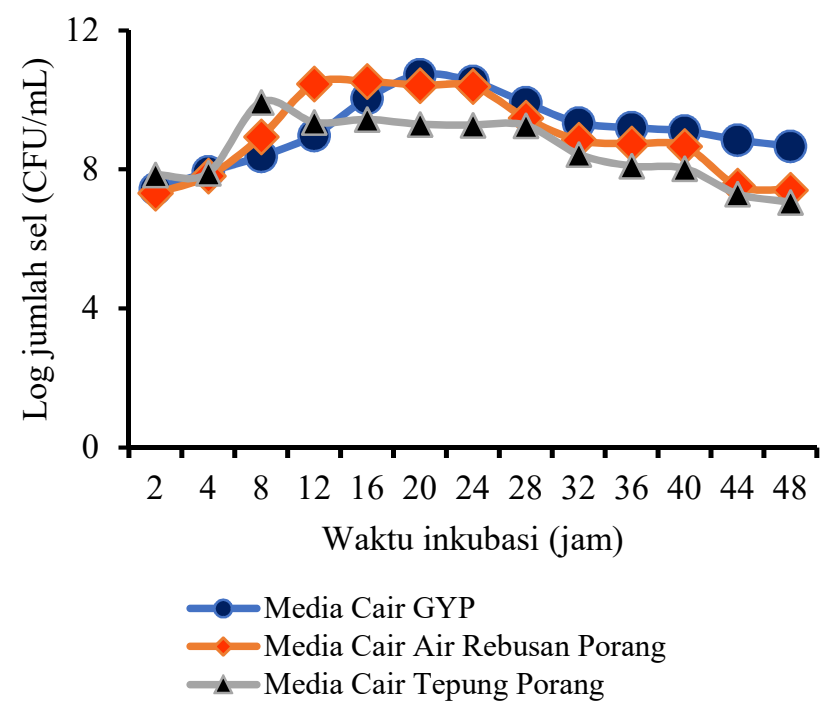

Gambar 1. Pola pertumbuhan L. casei FNCC0900 pada media pertumbuhan

Pola pertumbuhan L. casei FNCC0900 pada Gambar 1. menunjukkan adanya fase adaptasi (lag) yang diduga terjadi pada waktu inkubasi ke-0 hingga ke-4 (4 jam) baik pada Media Cair GYP dan media berbasis umbi porang. Hal tersebut berbeda dengan penelitian yang dilakukan oleh Mardalena yang menyatakan bahwa fase log $L$. casei yang diinokulasikan pada Media Cair MRS terjadi selama 4 jam [12]. Panjang atau pendeknya waktu adaptasi ditentukan oleh jumlah sel yang diinokulasikan, kondisi fisiologis dan morfologis yang sesuai serta media pertumbuhan yang dibutuhkan, sedangkan fase adaptasi pada penelitian ini dipengaruhi oleh adanya jenis media pertumbuhan yaitu media pertumbuhan sintetis (buatan) berupa Media Cair GYP dan media pertumbuhan alami berupa Media Cair Air Rebusan Porang dan Media Cair Tepung Porang dengan kepadatan sel yang diinokulasikan pada masingmasing jenis media sama [13]. Jenis media pertumbuhan yang digunakan pada penelitian ini mampu mempengaruhi kepadatan sel dan lama waktu setiap fase yang akan mempengaruhi juga pada waktu generasi.

Fase kedua dari pola pertumbuhan adalah fase eksponensial (log), pada Gambar 1 menunjukkan bahwa diduga fase eksponensial (log) terjadi pada waktu inkubasi ke-8 hingga ke-16 untuk Media Cair GYP, pada Media Cair Air Rebusan Porang terjadi pada waktu inkubasi ke-8 hingga ke-12, sedangkan pada Media Cair Tepung Porang fase eksponensial diduga terjadi pada waktu inkubasi ke-4 hingga ke-8. Fase eksponensial (log) pada Media Cair Air Rebusan Porang dan Media Cair Tepung Porang memiliki periode waktu fase eksponensial (log) yang sama yaitu 4 jam, hal ini diduga disebabkan oleh adanya kemampuan L. casei untuk menghidrolisis glukomannan pada umbi porang menjadi manooligosakarida dengan bantuan enzim mananase dan menghidrolisis pati dengan bantuan enzim amilase yang dihasilkan oleh L. casei. Manooligosakarida dapat berperan sebagai nutrisi untuk pertumbuhan bakteri probiotik salah satunya L.casei [14].

Fase berikutnya adalah fase stasioner, pada Gambar 1 diduga fase ini terjadi pada waktu inkubasi ke-20 hingga ke-24 untuk Media Cair GYP, pada Media Cair Air Rebusan Porang fase stasioner terjadi pada waktu inkubasi ke-16 hingga ke-24, sedangkan pada Media Cair Tepung Porang terjadi pada waktu inkubasi ke-12 hingga ke-28. Berdasarkan penelitian yang dilakukan Mardalena[12], fase stasioner L. casei FNCC0900 yang diinokulasikan pada Media Cair MRS memiliki periode fase stasioner selama $16 \mathrm{jam}$, hal tersebut sesuai dengan lama fase stasioner L. casei FNCC0900 pada Media Cair Tepung Porang. Kondisi mikroba pada fase stasioner mengalami penurunan aktivitas yang disebabkan oleh faktor lingkungan yang mulai tidak menguntungkan, berkurangnya faktor pertumbuhan seperti vitamin, unsur mineral, dan nutrisi dalam media pertumbuhan, dan terjadinya akumulasi autotoksin atau senyawa penghambat dalam media pertumbuhan [13].

Fase terakhir adalah fase kematian yang merupakan fase mulai berhentinya segala aktivitas sel. Berdasarkan pada Gambar 1, fase kematian ditandai dengan adanya 
penurunan grafik kurva pertumbuhan L. casei FNCC0900 yang terjadi pada waktu inkubasi ke-28 untuk Media Cair GYP dan Media Cair Air Rebusan Porang, sedangkan untuk Media Cair Tepung Porang fase kematian terjadi pada waktu inkubasi ke- 32. Fase kematian menunjukkan jumlah populasi yang mati lebih banyak daripada jumlah populasi sel yang tumbuh, dalam kondisi ini cadangan makanan sudah sangat menipis sehingga kurang mendukung untuk pertumbuhan populasi sel [15].

\section{Perubahan $\mathrm{pH}$ pada Media Pertumbuhan}

Faktor yang mempengaruhi laju pertumbuhan bakteri salah satunya adalah $\mathrm{pH}$. Asam organik yang dihasilkan oleh adanya pertumbuhan $L$. casei seperti asam laktat, asam asetat, dan asam piruvat mengakibatkan terjadinya akumulasi produk akhir asam dan penurunan $\mathrm{pH}$ pada media pertumbuhan [16]. Berdasarkan pengukuran nilai $\mathrm{pH}$ yang telah dilakukan, didapatkan hasil bahwa pada ketiga jenis media pertumbuhan telah mengalami penurunan $\mathrm{pH}$ dalam waktu 48 jam yang dapat dilihat pada Gambar 2.

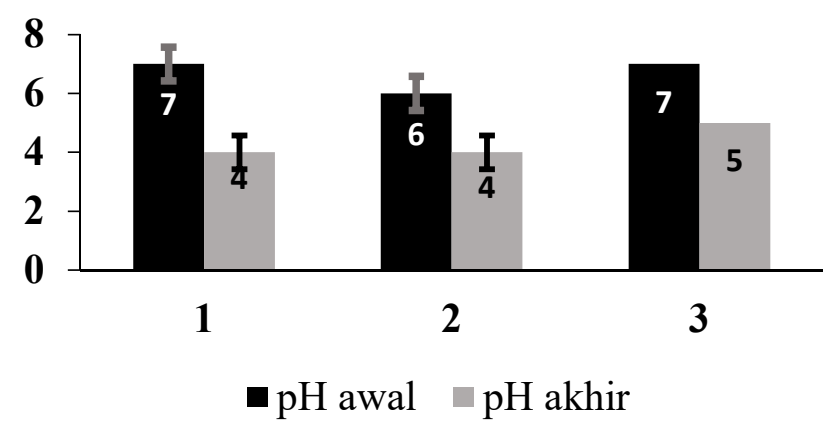

Gambar 2. Perubahan nilai $\mathrm{pH}$ pada media pertumbuhan. (1) Media Cair GYP (2) Media Cair Air Rebusan Porang (3) Media Cair Tepung Porang.

Berdasarkan Gambar 2, diketahui bahwa Media Cair GYP mengalami penurunan nilai $\mathrm{pH}$ dari 7 menjadi 4, kemudian Media Cair Air Rebusan Porang dari 6 menjadi 4, dan pada Media Cair Tepung Porang penurunan $\mathrm{pH}$ terjadi dari 7 menjadi 5. Bakteri L. casei FNCC0900 yang tumbuh pada Media Cair GYP lebih aktif melakukan metabolisme terutama dalam meningkatkan produksi asam organik yang dapat menurunkan nilai $\mathrm{pH}$ pada media. Hal tersebut diduga L. case $i$ FNCC0900 lebih mampu memanfaatkan gulagula sederhana yang terkandung dalam Media Cair
GYP sebagai sumber energi dibandingkan kelompok gula pada media berbasis umbi porang.

Faktor lain yang menyebabkan adanya penurunan nilai $\mathrm{pH}$ pada media yaitu waktu inkubasi, semakin lama waktu inkubasi maka akan semakin asam $\mathrm{pH}$ media pertumbuhan [17]. Penurunan nilai $\mathrm{pH}$ pada media pertumbuhan terjadi disebabkan oleh adanya peningkatan kadar asam organik yang dihasilkan oleh isolat L. casei FNCC0900. Tingginya kadar asam organik yang dihasilkan dapat mengindikasikan tingginya aktivitas metabolisme yang berlangsung sehingga kemampuan L. casei FNCC0900 untuk menurunkan nilai $\mathrm{pH}$ juga semakin optimal.

\section{Kepadatan Sel dan Waktu Generasi Lactobacillus casei FNCC0900}

Perhitungan kepadatan sel L. casei FNCC0900 pada masing-masing media pertumbuhan dilakukan dengan menginokulasikan bakteri L. casei FNCC0900 pada Media Cair GYP, Media Cair Air Rebusan Porang dan Media Cair Tepung Porang. Bakteri L. casei FNCC0900 yang diinokulasikan berumur 18 jam, kepadatan sel tertinggi diambil pada saat awal terjadinya fase eksponensial (log). Kepadatan sel L. casei FNCC0900 yang tumbuh pada Media Cair GYP dan media berbasis umbi porang disajikan pada Tabel 1 .

Tabel 1. Kepadatan Sel L. casei FNCC0900 pada Awal Fase Eksponensial (Log)

\begin{tabular}{cc}
\hline Jenis media pertumbuhan & $\begin{array}{c}\text { Rata-rata jumlah sel } \\
\text { bakteri }(\mathrm{CFU} / \mathrm{mL})\end{array}$ \\
\hline Media Cair GYP & $5,3 \times 10^{10}$ \\
Media Cair Air Rebusan & $3,0 \times 10^{10}$ \\
Porang & $8,0 \times 10^{9}$ \\
Media Cair Tepung Porang & \\
\hline
\end{tabular}

Berdasarkan Tabel 1 dapat diketahui bahwa kepadatan sel L. casei FNCC0900 yang tumbuh pada masing-masing jenis media pertumbuhan berbedabeda. Media Cair Tepung Porang memiliki rata-rata jumlah sel yang sangat rendah dibandingkan pada Media Cair Air Rebusan Porang dan Media Cair GYP. Hal tersebut diduga dikarenakan oleh kurang larutnya protein yang terikat pada tepung sehingga mampu menyebabkan kurang melimpahnya kandungan nutrisi yang dibutuhkan untuk pertumbuhan $L$. casei FNCC0900. Protein berperan sebagai sumber nitrogen utama yang mampu meningkatkan laju pertumbuhan dan aktivitas mikroorganisme [18]. 
Kepadatan sel L. casei FNCC0900 tertinggi terdapat pada Media Cair GYP, hal tersebut dikarenakan adanya komposisi kimia yang terkandung dalam Media Cair GYP seperti yeast extract dan beef extract yang memiliki kandungan asam amino, peptida dan vitamin B kompleks sehingga mampu meningkatkan laju pertumbuhan mikroorganisme serta berfungsi sebagai sumber nitrogen utama yang berperan dalam produksi asam laktat. Ketersediaan nutrisi pada media pertumbuhan menjadi faktor yang penting untuk meningkatkan laju pertumbuhan bakteri (Wardani dan Rudiana)[18]. Kepadatan sel tertinggi pada media berbasis umbi porang terdapat pada Media Cair Air Rebusan Porang, tingginya kepadatan sel L. casei FNCC0900 yang tumbuh pada Media Cair Air Rebusan Porang disebabkan oleh adanya proses perebusan yang mampu melarutkan kandungan nutrisi pada umbi ke dalam air rebusan, kandungan nutrisi yang terlarut dalam air rebusan meliputi garam mineral, vitamin $C$, protein yang larut dalam air, dan vitamin B kompleks yang berperan untuk meningkatkan laju pertumbuhan L. casei FNCC0900. Proses perebusan juga sangat berpengaruh pada karbohidrat, sehingga kandungan pati pada umbi dapat larut dengan baik [19].

Proses pertumbuhan sel bakteri membutuhkan waktu untuk membelah diri dari satu sel menjadi dua sel, waktu yang diperlukan untuk memperbanyak diri tersebut disebut dengan waktu generasi. Waktu generasi L. casei FNCC0900 dihitung pada saat sel sedang aktif membelah yaitu pada fase eksponensial $(\log )$ (Sutrisna, dkk)[20]. Waktu generasi L. casei FNCC0900 yang diinokulasikan pada Media Cair GYP, Media Cair Air Rebusan Porang dan Media Cair Tepung Porang memiliki hasil yang berbeda-beda, hasil perhitungan waktu generasi $L$. casei dapat dilihat pada Tabel 2.

Tabel 2 Waktu Generasi L. casei FNCC0900 pada Media Cair GYP dan Media Berbasis Umbi Porang

\begin{tabular}{ccc}
\hline $\begin{array}{c}\text { Jenis media } \\
\text { pertumbuhan }\end{array}$ & $\begin{array}{c}\text { Jumlah } \\
\text { generasi (n) }\end{array}$ & $\begin{array}{c}\text { Waktu generasi } \\
\text { (menit) }\end{array}$ \\
\hline $\begin{array}{c}\text { Media Cair GYP } \\
\text { Media Cair Air }\end{array}$ & 5,51 & 87,04 \\
$\begin{array}{c}\text { Rebusan Porang } \\
\text { Media Cair }\end{array}$ & 5,05 & 47,53 \\
Tepung Porang & 6,78 & 35,42 \\
\hline
\end{tabular}

Berdasarkan hasil perhitungan waktu generasi pada Tabel 2, L. casei FNCC0900 yang tumbuh pada Media Cair GYP memiliki waktu generasi paling lama dibandingkan media berbasis umbi porang yaitu 87,04 menit. Hasil perhitungan waktu generasi bakteri $L$. casei FNCC0900 pada Media Cair GYP sebanding dengan pola pertumbuhannya. Berdasarkan Gambar 4.1, dapat diketahui bahwa L. casei FNCC0900 yang tumbuh pada Media Cair GYP memiliki periode fase eksponensial (log) yang lebih lama yaitu selama 8 jam dibandingkan media berbasis umbi porang, namun memiliki kepadatan sel tertinggi dibandingkan media berbasis umbi porang.

Bakteri L. casei FNCC0900 yang tumbuh pada media berbasis umbi porang memiliki lama fase eksponensial (log) yang sama yaitu selama 4 jam, namun memiliki waktu generasi yang berbeda. Waktu generasi L. casei FNCC0900 yang tumbuh pada Media Cair Air Rebusan Porang sebesar 47,53 menit sedangkan waktu generasi L. casei FNCC0900 yang tumbuh pada Media Cair Tepung Porang terjadi lebih singkat yaitu 35,42 menit dengan kepadatan sel yang lebih rendah. Menurut Fauziah, dkk[21], waktu generasi yang telah dihitung dari masing-masing jenis media pertumbuhan dapat digunakan untuk menentukan tingkat keaktifan L. casei FNCC0900 dalam melakukan proses metabolisme, semakin cepat waktu generasi yang terjadi, maka semakin aktif mikroba tersebut dalam melakukan proses metabolisme.

Berdasarkan perhitungan waktu generasi pada Tabel 2, bakteri L. casei FNCC0900 yang tumbuh pada Media Cair GYP mampu menghasilkan rata-rata 6 generasi selama 87,04 menit. Pertumbuhan L. casei FNCC0900 pada Media Cair Air Rebusan Porang mampu menghasilkan rata-rata 5 generasi selama 47,53 menit sedangkan pada Media Cair Tepung Porang L. casei FNCC0900 mampu menghasilkan ratarata 7 generasi selama 35,42 menit. Perbedaan waktu generasi dan jumlah generasi yang dihasilkan dari masing-masing media pertumbuhan dapat menunjukkan bahwa bakteri L. casei FNCC0900 lebih aktif dalam melakukan aktivitas metabolisme pada media berbasis umbi porang dibandingkan pada Media Cair GYP. 


\section{KESIMPULAN}

Bakteri L. casei FNCC0900 mampu tumbuh pada media berbasis umbi porang, terutama pada Media Cair Air Rebusan Porang. Periode fase eksponensial (log) yang terjadi lebih singkat pada Media Air Rebusan Porang dengan kepadatan sel yang dihasilkan lebih tinggi yaitu sebesar $3,0 \times 10^{10}$ dibandingkan pada Media Cair Tepung Porang. Waktu generasi pada Media Cair Air Rebusan Porang terjadi lebih lama dengan kepadatan sel yang dihasilkan lebih sedikit dibandingkan pada Media Cair Tepung Porang. Bakteri L. casei FNCC0900 lebih mampu menurunkan nilai $\mathrm{pH}$ pada Media Cair GYP dibandingkan media berbasis umbi porang dan kepadatan sel $L$. casei FNCC0900 pada Media Cair GYP lebih tinggi dengan waktu generasi yang lebih lama dibandingkan pada media berbasis umbi porang.

\section{DAFTAR PUSTAKA}

[1] Sari, Ika Puspita., E. Lukitaningsih., Rumiyati dan I. M. Setiawan. 2013. Indek Glikemik Uwi, Gadung dan Talas yang Diberikan pada Tikus. Traditional Medical Journal. 18 (3): 127-131.

[2] Suskovic, J, B. Kos, J. Goreta, dan S. Matosic. 2001. Role of Lactic Acid Bacteria and Bifidobacteria in Symbiotic Effect. Food Technology Biotechnology. 39 (3): $227-235$.

[3] Prastyaharasti, L.M dan E. Zubaidah. 2014. Evaluasi Pertumbuhan Lactobacillus casei dalam Medium Susu Skim yang Disubstitusi Tepung Beras Merah. Jurnal Pangan dan Agroindustri.2 (4): 285-296.

[4] Yunus, Y. dan E. Zubaidah. 2015. Pengaruh Konsentrasi Sukrosa dan Lama Fermentasi Terhadap Viabilitas Lactobacillus casei Selama Penyimpanan Beku Velva Pisang Ambon. Jurnal Pangan dan Agroindustri. 3 (2): 303-312.

[5] Supriati, Yati. 2016. Keanekaragaman Iles-Iles (Amorphophallus spp.) dan Potensinya untuk Industri Pangan Fungsional, Kosmetik, dan Bioetanol. Jurnal Litbang Pertanian. 35 (2): 69-80.

[6] Betoret, E., N. Betoret., D. Vidal., dan P. Foto. 2011. Functional Foods Development: Trends and Technologies. Trends Food Science \& Technology. (22): 498-508.

[7] Wigoeno, Y. A., R. Azrianingsih dan A. Roosdiana. 2013. Analisis Kadar Glukomanan Pada Umbi Porang (Amorphophallus muelleri Blume) Menggunakan Refluks Kondensor. Jurnal Biotropika. 1 (5): 231-234.
[8] Sari, R dan Suhartati. 2015. Tumbuhan Porang: Prospek Budidaya sebagai Salah Satu Sistem Agroforestry. Info Teknis EBONI. 12 (2): 97 - 110.

[9] Aryanti, N dan K.Y. Abidin. 2015. Ekstraksi Glukomanan Dari Porang Lokal (Amorphophallus oncophyllus dan Amorphophallus muelleri Blume). Metana. 11 (1): 21-30.

[10] Rahmawati, I. S., E. Zubaida dan E. Saparianti. 2015. Evaluasi Pertumbuhan Isolat Probiotik (Lactobacillus casei dan Lactobacillus plantarum) dalam Medium Fermentasi Berbasis Ubi Jalar (Ipomoea batatas L.) selama Proses Fermentasi (Kajian Jenis Isolat dan Jenis Tepung Ubi Jalar). Jurnal Aplikasi Teknologi Pangan. 4 (4): 133-140.

[11] Najgebauer-Lejko, DE., M. Sady.,T. Grega dan M. Walczycka. 2011. The impact of tea supplementation on microflora, $\mathrm{pH}$ and antioxidant capacity of yoghurt. International Journal of Dairy Science. (21): 568-574.

[12] Mardalena. 2016. Fase Pertumbuhan Isolat Bakteri Asam Laktat (BAL) Tempoyak Asal Jambi yang Disimpan Pada Suhu Kamar. Jurnal Sains Peternakan Indonesia. 11 (1): 58-64.

[13] Yuliana, N. 2008. Kinetika Pertumbuhan Bakteri Asam Laktat Isolat T5 yang Berasal dari Tempoyak. Jurnal Teknologi Industri dan Hasil Pertanian. 13(2): 108114.

[14] Sigres, D.P dan A. Sutrisno. 2015. Enzim Mananase dan Aplikasi di Bidang Industri: Kajian Pustaka. Jurnal Pangan dan Agroindustri. 3 (3): 899-908.

[15] Nurhajati, T. K. Soepranianondo dan W. P. Lokapirnasari. 2014. Uji Aktivitas Pertumbuhan Enterobacter cloacae Selulolitik Aerob Rumen-1 Isolat Asal Limbah Cairan Rumen Sapi Peranakan Ongole. Jurnal Veteriner. 17(3): 383-388.

[16] Imron, M. F. dan I. F. Purwanti. 2016. Uji kemampuan bakteri Azotobacter S8 dan Bacillus subtilis untuk menyisihkan trivalent chromium $(\mathrm{Cr} 3+)$ pada limbah cair. Jurnal Teknik ITS. 5 (1): 1-7.

[17] Khoiriyah, H dan P. Ardiningsih. 2014. Penentuan Waktu Inkubasi Optimum Terhadap Aktivitas Bakteriosin Lactobacillus sp. RED4. Jurnal Kimia Khatulistiwa. 3 (4): 52-56.

[18] Wardani, R.Y dan R. Agustini. 2017. Pengaruh konsentrasi Yeast Hydrolysate Enzimatic (YHE) sebagai suplemen media kultur untuk pertumbuhan Lactobacillus bulgaricus. Journal of Chemistry. 6 (1): 25-30.

[19] Sundari, D., Almasyhuri dan A. Lamid. 2015. Pengaruh proses pemasakan terhadap komposisi zat gizi bahan pangan sumber protein. Media Litbangkes. 25 (4): 235 -242 . 
[20] Sutrisna, R., N. Ekowati dan D. Rahmawati. 2013. Uji daya hambat isolat bakteri asam laktat usus itik (Anas domestica) pada bakteri gram positif dan pola pertumbuhan isolat bakteri usus itik pada media MRS Broth. Jurnal Penelitian Pertanian Terapan. 13 (1): 5259.

[21] Fauziah, P. N., J. Nurhajati dan Chrysanti. 2018. Pengaruh laju pertumbuhan dan waktu generasi terhadap penghambatan pertumbuhan koloni Klebsiella pneumoniae strain ATCC 700603, CTL538 dan S941 oleh Lactobacillus bulgaricus KS1 dalam soyghurt. Jurnal Kesehatan Kartika. 08 (1): 1-14. 